\title{
Pengaruh Tax Morale Terhadap Niat Untuk Patuh Calon Wajib Pajak Dengan Kesadaran Pajak Sebagai Variabel Moderasi
}

(Studi Kasus Pada Mahasiswa UST Sebagai Calon Wajib Pajak)

\author{
Dewi Kusuma Wardani ${ }^{1}$, Yuli Prihatni ${ }^{2}$, Ayu Wulandari ${ }^{3}$ \\ ${ }^{1}$ Fakultas Ekonomi Universitas Sarjanawiyata Tamansiswa, ${ }^{2}$ Fakultas Keguruan dan IImu \\ Pendidikan, ${ }^{3}$ Fakultas Ekonomi Universitas Sarjanawiyata Tamansiswa \\ Email:1d3wikusuma@gmail.com, 2yuli_prihatni@ustjogja.ac.id, \\ 3ayuwulandari52000@gmail.com
}

\begin{abstract}
This study aims to examine whether tax morale affects the obedient intentions of prospective taxpayers with tax awareness as a moderating variable. This study uses descriptive quantitative methods and primary data using a questionnaire. The number of samples in this study were 100 respondents from the undergraduate program at Tamansiswa University, Yogyakarta. Sampling in this study using convenience sampling technique. This study provides results that tax morale has no effect on tax compliance intentions, tax awareness cannot strengthen the positive effect of tax morale on tax compliance intentions.
\end{abstract}

Keywords: Tax Morale, Tax Compliance Intention, Tax Awareness

\begin{abstract}
Abstrak
Penelitian ini memiliki tujuan untuk menguji apakah tax morale berpengaruh terhadap niat untuk patuh calon wajib pajak dengan kesadaran pajak sebagai variabel moderasi. Penelitian ini menggunakan metode deskripsi kuantitatif dan data primer dengan menggunakan kuesioner. Jumlah sampel dalam penelitian ini sebanyak 100 responden mahasiswa yang ada di Universitas Sarjanawiyata Tamansiswa Yogyakarta. Pengambilan sampel dalam penelitian ini menggunakan teknik convenience sampling. Penelitian ini memberikan hasil bahwa tax morale tidak berpengaruh terhadap niat patuh pajak, kesadaran pajak tidak dapat memperkuat pengaruh positif tax morale terhadap niat patuh pajak.
\end{abstract}

Kata Kunci: Tax Morale, Niat Patuh Pajak, Kesadaran Pajak

\section{PENDAHULUAN}

Pajak merupakan suatu elemen penting dalam penerimaan negara terutama untuk keberlangsungan ekonomi negara, hasil dari pendapatan pungutan tersebut dipergunakan sebagai anggaran pada saat melaksanakan tujuan negara dalam peningkatan kesejahteraan masyarakat dengan pembangunan dan pengembangan fasilitas umum [1]. Pentingnya peranan pajak dalam pembangunan dan pengembangan fasilitas umum membutuhkan anggaran yang tidak sedikit [2]. Proses pembangunan yang membutuhkan pendanaan yang tidak sedikit, mendorong masyarakat untuk membayar kewajiban perpajakan karena penerimaan harus sesuai dengan yang dibutuhkan agar pembangunan dapat terlaksana [3].

Tabel 1.1 Realisasi Pajak Daerah di Kota Yogyakarta

\begin{tabular}{cccc}
\hline Tahun & Target & $\begin{array}{c}\text { Realisasi } \\
\text { Penerimaan } \\
\text { Pajak }\end{array}$ & Pertumbuhan \\
\hline 2019 & Rp 420,7 Miliar & Rp 128,05 & $30,44 \%$
\end{tabular}




\begin{tabular}{lccc} 
& Miliar & \\
2020 & Rp 451,1 Miliar & Rp 120,4 Miliar & $26,7 \%$ \\
\hline
\end{tabular}

Sumber: Antaranews.com (2020)

Dari penjelasan tabel tersebut bisa diketahui bahwa sumber pendapatan melalui perpajakan pada daerah Yogyakarta mengalami penurunan dan belum terelasasi sesuai dengan yang ditetapkan oleh pemerintah. Pada tahun 2019 target yang ditetapkan senilai Rp420,7 Miliar akan tetapi yang terealisasi sebesar Rp128,05 Miliar serta mengalami penurunan lagi pada tahun 2020 dari target yang ditetapkan senilai Rp451,1 Miliar tetapi terealisasi sebesar Rp120,4 Miliar. Sebagian besar pendapatan negara berasal dari perpajakan oleh karena itu perpajakan dijadikan sebagai pendapatan utama dalam hal penghasilan negara yang terbilang berhasil dan diharapkan dapat berperan terhadap kemakmuran dan kesejahteraan bangsa dimana mempengaruhi laju perkembangan ekonomi di Indonesia, maka penerimaan pajak perlu peningkatan yang signifikan [4]. Pengoptimalan pendapatan perpajakan membutuhkan peran aktif dari wajib pajak ataupun calon wajib pajak sehingga tindakan patuh dalam memenuhi kewajiban perpajakan dapat meningkat semata-mata tidak hanya mengandalkan peran dari aparatur pajak saja [5].

Fenomena belum optimalnya realisasi pendapatan pajak yang ada di Indonesia diakibatkan sedikitnya tindakan patuh pada saat pemenuhan tanggung jawab perpajakannya. Di Indonesia masalah kepatuhan pajak ini masih terbilang rendah dengan tata cara pembayaran yang menyerahkan tanggung jawab sepenuhnya kepada wajib pajak sendiri karena mengharuskan wajib pajak untuk membayar secara sukarela kewajibanya, salah satunya masalah yang menjadi fokus utama bagi para pembuat keputusan kebijakan ekonomi adalah memotivasi wajib pajak untuk lebih patuh terhadap kewajiban perpajakannya karena masih ada masyarakat yang belum sadar untuk memenuhi kewajiban perpajakannya [6]. Memperkenalkan pentingnya pajak lebih awal memberikan secercah harapan atas pertanyaan menurunnya kesadaran dalam diri masyarakat terhadap kewajiban perpajakannya yang sering terjadi saat ini, pemberian edukasi mengenai pajak kepada calon wajib pajak khususnya mahasiswa dirasakan perlu karena asumsinya adalah di kemudian hari mereka akan menjadi bagian dari masyarakat yang menjalankan aktivitas ekonominya atau lebih tepatnya mereka sebagai calon wajib pajak yang nantinya akan melaksanakan kewajiban perpajakan di saat mereka telah bekerja, dan sekarang ini banyak dari kalangan mahasiswa sudah melakukan berbagai kegiatan usaha bisnis dari yang pendapatannya kecil hingga ratusan juta rupiah, menumbuhkan niat patuh pajak dalam diri calon wajib pajak terutama mahasiswa dianggap penting untuk penerimaan negara [7].

Beberapa faktor yang mempengaruhi mahasiswa sebagai calon wajib pajak dalam menumbuhkan niat patuh pajak. Niat patuh pajak merupakan keinginan manusia dalam bertindak patuh atau tidak patuh [8]. Niat untuk mematuhi pajak memicu munculnya perilaku patuh pajak [8]. Niat patuh pajak diartikan sebagai niat atau kemauan untuk patuh melalui kesadaran yang ditanamkan dalam diri seseorang akan bergunanya kontribusi perpajakan untuk penerimaan negara dengan menumbuhkan nilai-nilai karakter untuk sadar dan berpandangan positif terhadap kewajiban perpajakan, tingkat kepatuhan dan mempertahankan kepatuhan dari wajib pajak merupakan masalah yang cukup serius untuk diperhatikan bagi para pembuat kebijakan di negara pada saat ini [3].

Faktor pertama adalah tax morale merupakan prinsip dasar seseorang dalam suatu keputusan terkait perilaku yang diambil [4]. Melalui hal ini, tentunya masing-masing individu berperan penting dalam membuat keputusan taat pajak atau tidak karena hal ini dipengaruhi oleh prinsip atau nilai yang dianut individu yang bersangkutan [9]. Pembayaran pajak tidak terlepas dari tingkah laku wajib pajak maka tindakan patuh terhadap pajak sangat dipengaruhi moralitas pajak yang dimilki oleh tiap individu [10]. Keputusan bijak yang mengutamakan moralitas dalam menentukan berbagai keputusan akan bersikap patuh dibandingkan individu yang lain dalam pembayaran pajak [4]. Hal ini sejalan dengan penelitian [4] menyatakan bahwa moralitas pajak berpengaruh positif terhadap kepatuhan wajib pajak. Sebaliknya, penelitian ini bertolak belakang dengan penelitian dari [4] menyatakan moral wajib pajak tidak berpengaruh positif terhadap kepatuhan wajib pajak.

Kesadaran pajak memperkuat pengaruh positif tax morale terhadap niat patuh pajak, kesadaran pajak dilihat dari pandangan wajib pajak terhadap ketersediaan dalam pembayaran 
kewajibannya dapat membantu pembangunan negara dan tidak melakukan hal yang dapat merugikan negara salah satunya penunggakan pembayaran pajak yang merupakan bentuk dari tindakan tidak patuh [11]. Tax morale dipandang sebagai motivasi dasar dalam pembayaran pajak [4]. Tingginya tingkat kesadaran akan mempengaruhi motivasi yang timbul pada tiap individu untuk pemenuhan kewajibannya, dikarenakan pembentukan tax morale atas dasar keterlibatan tiap inidividu, keyakinan, kebanggaan, sistem perpajakan dengan menumbuhkan motivasi dasar dalam diri wajib pajak, dan melalui kesadaran pajak maka pengapresiasian warga negara kepada negara bisa dilihat dari patuh atau tidaknya dalam hal perpajakan [12]. Melalui kesadaran wajib pajak diharapkan bisa berperan aktif dalam melaksanakan tanggung jawabnya [13]. Hal ini sejalan dengan penelitian [14] menyatakan kesadaran perpajakan berpengaruh positif terhadap kepatuhan perpajakan. Sebaliknya, penelitian ini bertolak belakang terhadap penelitian [15] menyatakan kesadaran wajib pajak tidak berpengaruh pada kepatuhan.

Penelitian ini memiliki dua tujuan. Pertama, apakah tax morale berpengaruh positif terhadap niat untuk patuh calon wajib pajak. Kedua apakah kesadaran pajak dapat memoderasi pengaruh positif tax morale terhadap niat untuk patuh calon wajib pajak. Kebaharuan dari penelitian ini adalah meneliti niat untuk patuh calon wajib pajak, yang mana belum banyak diteliti. Selain itu, penelitian ini menambahkan variabel moderasi kesadaran pajak dalam pengaruh positif tax morale terhadap niat untuk patuh.

\section{TINJAUAN TEORI DAN PENGEMBANGAN HIPOTESIS}

Teori perilaku terencana biasanya disebut dengan teori yang dilandasi pada asumsi bahwa setiap individu menggunakan informasi yang memungkinkan bagi individu secara terstruktur sebagai makhluk yang rasional [16]. Teori ini salin terkait terhadap penelitian yang saya lakukan karena perilaku patuh calon wajib pajak pada saat menunaikan kewajibannya dalam perpajakan disebabkan oleh niat yang timbul dalam diri calon wajib pajak, terjadinya tindakan patuh apabila calon wajib pajak bisa mengimplementasikan niat yang timbul di dalam dirinya atas dasar pemenuhan kewajiban pajaknya [17]. Hal ini bersifat signifikan dengan tax morale karena apabila calon wajib pajak memiliki tax morale sebagai motivasi dasar dalam berperilaku patuh yang didasari kemauan, kesadaran serta kesungguhan yang akan berpengaruh serta memberikan dorongan untuk para calon wajib pajak senantiasa patuh perpajakan apabila sudah menanamkan persepsi baik dari masing-masing individu calon wajib pajak [14].

\section{Pengaruh positif Tax Morale terhadap Niat Patuh Pajak}

Moral pajak bisa diartikan sebagai motivasi yang timbul diluar faktor ekonomi yang bekerja mengikuti mata batin seseorang untuk bersikap patuh yang timbul dari motivasi dasar tiap inidivu [18]. Hal ini juga dikatakan oleh [5] bahwa tindakan patuh dapat disebabkan oleh moral pajak yang dimiliki individu. Pada hakekatnya pembayaran pajak merupakan tindakan yang berkaitan dengan tingkah laku wajib pajak sendiri. Moral pajak diukur berdasar individu wajib pajak yaitu pada sikap, perilaku, dan pendirian yang dimiliki sebagai dasar untuk melaksanakan kegiatan patuh terhadap pajak. Hal ini bisa dinilai dari rasa percaya tiap individu terhadap otoritas perpajakan serta adanya rasa yakin untuk berkontribusi pada negara dalam pembayaran pajak, jika dalam diri wajib pajak mempunyai moral yang baik maka kemungkinan besar akan lebih mudah untuk bersikap patuh terhadap pajak [19]. Kepercayaan terhadap pemerintah atau sistem hukum yang berlaku mampu meningkatkan motivasi dasar wajib pajak. Wajib pajak yang mengutamakan moral pada saat membuat keputusan membayar pajak maka akan lebih patuh dibandingkan dengan wajib pajak lainnya [20].

Hal ini didukung dengan penelitian yang dilakukan oleh [19] \& [20] yang mengungkapkan bahwa moral pajak berpengaruh positif terhadap kepatuhan pajak. Berdasarkan uraian diatas, maka dapat dirumuskan hipotesis sebagai berikut :

\section{$\mathrm{H}_{1}: \quad$ Tax Morale berpengaruh positif terhadap niat patuh pajak}

\section{Kesadaran Pajak Memperkuat Pengaruh Positif Tax Morale terhadap Niat Patuh Pajak}

Kesadaran Pajak adalah pemahaman seseorang yang berwujud dalam sikap, perilaku, pemikiran, dan pengambilan tindakan dalam pemenuhan kewajiban sebagai masyarakat yang 
taat pajak dengan bersikap patuh berdasarkan undang-undang yang telah ditetapkan untuk mengetahui akan pentingnya kesadaran serta pemahaman secara mendalam mengenai pajak [2]. Kesadaran pajak juga wujud dari kepercayaan masyarakat melakukan pembayaran pajak sepenuhnya untuk pembiayaan negara serta dengan sukarela melakukan kewajiban perpajakannya [1]. Jika dikaitkan dengan tax morale, kesadaran yang tinggi akan pentingnya pajak secara tidak langsung akan mempengaruhi moral pajak dari masing individu menjadi semakin tinggi karena secara tidak mempengaruhi pembentukan moral individu seseorang, seperti sikap, cara berperilaku, merasa bersalah dan melaksanakan kewajiban pajaknya tanpa ada paksaan akan menumbuhkan niat patuh terhadap perpajakan [9]. Hal ini juga dikatakan [2] dengan adanya kesadaran pajak yang tinggi akan berakibat dalam pembentukan motivasi dasar dalam diri wajib pajak sehingga menumbuhkan niat patuh terhadap perpajakan.

Berdasarkan uraian diatas dapat dirumuskan hipotesis sebagai berikut :

\section{$\mathrm{H}_{2} \quad$ Kesadaran wajb pajak memperkuat hubungan positif tax morale terhadap niat patuh pajak.}

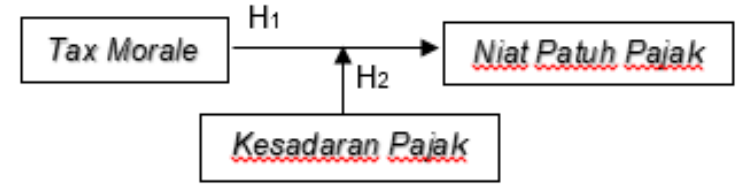

Gambar 1

Kerangka Pikir Penelitian

\section{METODE PENELITIAN}

Populasi yang ada pada penelitian ini seluruh mahasiswa pada Universitas Sarjanawiyata Tamansiswa Yogyakarta. Teknik yang digunakan pada saat pengambilan sampel ialah dengan metode Snowball Sampling dimana kuisoner dalam bentuk angket google form diberikan/diserahkan kepada kepada mahasiswa untuk disebarkan lagi kepada mahasiwa lain yang menjadi responden untuk memperoleh data yang lebih banyak [21]. Jumlah sampel sebanyak 100 responden, pengambilan sampel dilakukan pada mahasiswa yang ada di Universitas Sarjanawiyata Tamansiswa. Variabel dalam penelitian ini diukur melalui skala likert.

\section{Definisi Operasional Variabel Penelitian}

\section{Tax Morale (X)}

Moral pajak diartikan sebagai motivasi yang timbul pada individu yang mempercayai bahwasannya pajak merupakan kewajiban yang menjadi tanggung jawab kita bersama sebagai warga negara untuk keberlangsungan pemerintahan dan pembangungan fasilitas umum, maka setiap warga negara diharapkan bersikap patuh dapat pelaporan serta pembayaran pajaknya, diukur menggunakan beberapa indikator yang disesuaikan dari penelitian [10] yang telah dimodifikasi yang terdiri dari 4 (empat) indikator yaitu adanya niat untuk menaati peraturan perpajakan, kepercayaan terhadap pemerintah, kebanggaan nasional, dan sistem pajak.

\section{Niat Patuh Pajak (Y)}

Niat patuh pajak diartikan sebagai kecenderungan dan juga keputusan melakukan atau tidak melakukannya kewajiban pajaknya, diukur dengan menyesuaikan indikator yang digunakan oleh [22] terdapat 2 (dua) indikator yang telah dimodifikasi yaitu kecenderungan untuk melaksanakan kewajiban perpajakan dan keputusan untuk taat perpajakan.

\section{Kesadaran Pajak (Z)}

Kesadaran pajak adalah kesadaran akan hak serta kewajiban seseorang dalam pemenuhan kewajiban pembayaran pajak, pembayaran yang dilakukan tanpa adanya paksaan termasuk kedalam kepercayaan seseorang dalam pembayaran pajaknya untuk pembiayaan negara, diukur dengan menyesuaikan indikator yang telah dikembangkan oleh peneliti 
sebelumnya yaitu [1] yang telah dimodifikasi terdiri dari 3 (tiga) indikator yaitu kesadaran adanya hak dan kewajiban untuk membayar pajak, percaya bahwa membayar pajak untuk pembiayaan negara, dan dorongan diri untuk membayar pajak secara sukarela.

\section{Analisis Data}

Analisis data pada penelitian menggunakan metode analisis data menggunakan Partial Least Square dibantu software SmartPLS versi 3.0. yang dilakukan menggunakan tahap Uji Kecocokan Model Pengukuruan (Outer Model) untuk pengujian validity dan reliability konstruk laten serta Uji Kecocokan Model Struktural (Inner Model) dalam pengujian pengaruh antara konstruk atau variabel.

\section{HASIL DAN PEMBAHASAN}

\section{Tabel 3.1 Statistik Deskriptif}

\begin{tabular}{|c|c|c|c|c|c|c|c|c|}
\hline & $\mathrm{N}$ & Range & Min & Max & Sum & Mean & & $\begin{array}{c}\text { Std. } \\
\text { Deviation }\end{array}$ \\
\hline & Statistik & Statistik & Statistik & Statistik & Statistik & Statistik & $\begin{array}{l}\text { Std } \\
\text { Error }\end{array}$ & Statistik \\
\hline $\begin{array}{l}\text { Tax Morale } \\
\text { (X1) }\end{array}$ & 100 & 34 & 46 & 80 & 6247 & 62,47 & 698 & 6,977 \\
\hline $\begin{array}{l}\text { Niat Patuh } \\
\text { Pajak (Y) }\end{array}$ & 100 & 16 & 24 & 40 & 3140 & 31,40 & ,379 & 3,793 \\
\hline $\begin{array}{l}\text { Kesadaran } \\
\text { Pajak (Z) }\end{array}$ & 100 & 20 & 30 & 50 & 4042 & 40,42 & 507, & 5,066 \\
\hline $\begin{array}{l}\text { Valid N } \\
\text { (listwise) }\end{array}$ & 100 & & & & & & & \\
\hline
\end{tabular}

Atas hasil analisis statistik deskriptif pada tabel diatas membuktikan bahwa tax morale (X1) untuk 100 responden dengan nilai terkecil yaitu 46 dan nilai terbesar 80 . Rata rata jawaban setuju untuk pernyataan pada tax morale yakni 62,47 dan standard deviation sebesar 6,977. Nilai rangenya 34 dan nilai sum seluruh responden pada pernyataan tax morale adalah 6247.

Atas hasil analisis statistik deskriptif pada tabel diatas membuktikan bahwa niat patuh pajak $(Y)$ untuk 100 responden dengan nilai terkecil yaitu 24 dan nilai paling besar 40 . Rata rata jawaban setuju untuk pada niat patuh pajak yakni 31,40 dan standard deviation sebesar 3,739. Nilai rangenya 16 dan nilai sum seluruh responden pada pernyataan niat patuh pajak adalah 3140.

Atas hasil analisis statistik deskriptif pada tabel diatas membuktikan bahwa kesadaran pajak (Z) untuk 100 responden dengan nilai terkecil yaitu 30 dan terbesar 50 . Rata rata jawaban setuju untuk pernyataan pada kesadaran pajak yakni 40,42 dan standard deviation sebesar 5,066 . Nilai rangenya 20 dan nilai sum seluruh responden pada pernyataan kesadaran pajak 100 informan adalah 4042.

\section{Uji Validitas, Uji Reliabilitas}

Dari pengujian ini mengungkapkan semua item pernyataan dinyatakan valid. Dibuktikan dengan loading factor diatas 0,50 . Pada penelitian ini juga dilakukan uji reliability dengan SmartPLS dinyatakan reliable karena nilai composite reliability $(>0,7)$ dan cronbach's alpha $(>0,60)$.

\section{Tabel 3.2 Nilai $R$ - Square}

\begin{tabular}{|c|c|}
\hline Variabel & R-Square \\
\hline NPP & 0,819 \\
\hline
\end{tabular}


Berdasarkan tabel 4.7 memberikan hasil bahwa nilai R-Square untuk variabel NPP memiliki nilai sebesar 0,819 yang memiliki arti bahwa variabel NPP masuk dalam kategori kuat.

Tabel 3.4

\begin{tabular}{cccccc}
\hline & $\begin{array}{c}\text { Original } \\
\text { Sample }\end{array}$ & $\begin{array}{c}\text { Sample } \\
\text { Mean }\end{array}$ & $\begin{array}{c}\text { Standart } \\
\text { Error } \\
(\text { STERR })\end{array}$ & $\begin{array}{c}\boldsymbol{T} \\
\text { Statistic } \\
(\text { O/Sterr })\end{array}$ & $\begin{array}{c}\boldsymbol{P} \text { - } \\
\text { Values }\end{array}$ \\
\hline TM=>NPP & 0,040 & 0,057 & 0,077 & 0,515 & 0,607 \\
TM*KP=>NPP & $-0,075$ & $-0,064$ & 0,062 & 1,212 & 0,226 \\
\hline
\end{tabular}

Hasil yang diperoleh untuk nilai path coefficient diatas membuktikan bahwa hubungan antara TM dan NPP yakni tidak signifikan ditandainya nilai T-statistik $0,515(<1,96)$. Nilai original sample estimate yakni 0,040 yang membuktikan bahwa TM dan NPP tidak berpengaruh. Maka dari itu $\mathrm{H} 1$ didalam penelitian ini berarti mengungkap bahwa tax morale tidak berpengaruh signifikan terhadap niat patuh pajak.

Hubungan antara TM dan NPP melalui KP yaitu tidak signifikan ditandai dengan Tstatistik sebesar $1,212(<1,96)$ dan original sample sebesar $-0,075$ yang membuktikan hubungan antara TM dan NPP melalui KP tidak berpengaruh. Oleh karena itu hipotesis H3 dalam penelitian ini mengungkap bahwa kesadaran pajak tidak dapat memperkuat pengaruh positif tax morale terhadap niat paruh pajak.

\section{PEMBAHASAN}

\section{Pengaruh Tax Morale Terhadap Niat Patuh Pajak}

Hasil pengujian hipotesis 1 yang dilakukan bahwa tax morale tidak berpengaruh terhadap niat patuh pajak. Hal tersebut dibuktikan dengan nilai T statistik 0,515 dan besarnya nilai original sample estimate sebesar 0,040 sehingga $\mathrm{H} 1$ dalam penelitian ini tidak terdukung.

Tax morale tidak berpengaruh terhadap niat patuh pajak, disebabkan oleh calon wajib pajak belum mempunyai kewajiban moral untuk memiliki sikap patuh terhadap pajak yang berhubungan dengan pengambilan keputusan terhadap pajaknya nanti, serta belum munculnya motivasi dasar dalam diri calon wajib pajak untuk memiliki rasa bangga apabila menyisihkan penghasilannya untuk pembayaran pajak. Pendapat ini diperkuat dengan mayoritas responden menjawab setuju pada pernyataan saya tidak merasa bangga apabila membayar pajak. Hasil pengujian ini juga sejalan dengan Theory Planned Behaviour (TPB), dimana kesempatan untuk bersikap patuh tergantung dengan kesempatan yang dimiliki calon wajib pajak, ketika munculnya kesempatan maka calon wajib pajak harus mewujudkan niatnya baik itu positif ataupun negatif akan tetapi seringkali niat yang dipilih bertentangan dengan situasi pada lapangan yang bisa disebabkan oleh calon wajib pajak belum memahami bagaimana kondisi dilapangan karena memang belum berkewajiban terhadap pajak yang belum bisa untuk menunjukkan perilaku yang diniatkan tadi melalui moral pajak, dan juga disebabkan oleh rendahnya moral pajak pada calon wajib pajak menjadikan calon wajib pajak tidak memahami bahwa tax morale yang tumbuh melalui motivasi dasar tiap individu penting dalam pembentukan niat patuh perpajakan.

Hasil penelitian ini sejalan dengan penelitian [12] yang mengemukakan bahwa tax morale tidak berpengaruh terhadap kepatuhan pajak.

\section{Kesadaran Pajak Memperkuat Pengaruh Positif Tax Morale Terhadap Niat Patuh Pajak}

Hasil pengujian hipotesis 2 yang dilakukan bahwa adanya hubungan negatif antara tax morale dengan niat patuh pajak melalui kesadaran pajak. Hal tersebut dibuktikan dengan nilai T-statistik sebesar 1,212 $(<1,96)$ dan original sample sebesar $-0,075$ sehingga $\mathrm{H} 3$ dalam penelitian ini tidak terdukung.

Kesadaran pajak tidak dapat memperkuat pengaruh positif tax morale terhadap niat patuh pajak. Hal ini dikarenakan rendahnya kesadaran pajak dapat dilihat dari mayoritas menjawab setuju terhadap pernyataan membayar pajak tidak tepat waktu tidak akan merugikan negara, sama halnya dengan calon wajib pajak belum mengetahui bahwa segala tindakan Lisensi: Creative Commons Attribution 4.0 International (CC BY 4.0) 
pajak yang diambil akan berdampak baik untuk kesejahteraan negara akibat kurangnya kesadaran terhadap pajak membuat pendapatan negara menurun, sedikitnya pendapatan yang diperoleh dari pajak akan membuat pembangunan infrastuktur dan sarana prasarana jadi terhambat. Penelitian ini sejalan dengan Theory Planned Behaviour (TPB), dimana tiap individu percaya terhadap adanya faktor ataupun tidak dalam mendukung kegiatan apapun yang bisa menjadi penghambat untuk melakukan suatu tindakan tertentu atas dasar kepercayaan inidividu itu sendiri mengenai tingkat kesulitan untuk melaksanakan suatu hal berdasarkan pengamatan yang dilakukan oleh individu.

Hasil penelitian ini sejalan dengan penelitian [23] yang mengemukakan bahwa kesadaran pajak tidak berpengaruh terhadap kepatuhan pajak.

\section{KESIMPULAN DAN SARAN}

\section{Kesimpulan}

Penelitian ini dilakukan dengan menggunakan 100 responden ialah mahasiswa yang ada di Universitas Sarjanawiyata Tamansiswa Yogyakarta. Berdasarkan dilakukannya penelitian ini bisa ditarik kesimpulan bahwa tax morale tidak berpengaruh terhadap niat patuh pajak, kesadaran pajak tidak bisa memperkuat pengaruh tax morale terhadap niat patuh pajak.

\section{Keterbatasan Penelitian}

Penelitian ini hanya sebatas satu variabel independen yaitu tax morale, satu variabel dependen yaitu niat pauh pajak dan satu variabel moderasi yaitu kesadaran pajak dan juga penelitian ini hanya menggunakan satu sumber yaitu kuesioner, yang menjadikan data yang diambil hanya menggambarkan hasil dari jawaban responden, dalam hal ini kuesioner memiliki keterbatasan terkadang jawaban yang diberikan oleh responden belum bisa menunjukkan keadaaan yang sebenarnya. Hal ini disebabkan akibat responden tidak objektif atau tidak memahami pernyataan yang diajukan dalam kuesioner dengan baik.

\section{Saran}

\section{Bagi Universitas Sarjanawiyata Tamansiwa}

Berdasarkan hasil analisa dan kesimpulan yang dilakukan pada masing-masing variabel, ditemukan bahwa tax morale tidak berpengaruh terhadap niat patuh pajak. Universitas Sarjanawiyata Tamansiswa (UST) diharapkan bisa meningkatkan motivasi dalam diri tiap mahasiswa agar nantinya bisa menjadi wajib pajak yang memiliki moral dalam berperilaku patuh pada perpajakannya.

\section{Bagi Peneliti Selanjutnya}

Berdasarkan hasil analisa dan kesimpulan maka saran yang dapat diberikan dalam penelitian ini yaitu pada variabel dalam penelitian ini masih terbatas dengan 1 variabel independen, 1 variabel dependen dan 1 variabel moderasi yang digunakan, maka dari itu peneliti selanjtnya dapat menambahkan variabel baru atau berbeda seperti sosialisasi pajak dan pengetahuan ajak sebagai variabel independen. Peneliti selanjutnya diharapkan dapat menambah serta memperluas sampel penelitian, semakin banyak jumlah responden semakin baik hasil.

\section{REFERENCES}

[1] D. K. Wardani and R. Rumiyatun, "Pengaruh Pengetahuan Wajib Pajak, Kesadaran Wajib Pajak, Sanksi Pajak Kendaraan Bermotor, Dan Sistem Samsat Drive Thru Terhadap Kepatuhan Wajib Pajak Kendaraan Bermotor," J. Akunt., vol. 5, no. 1, p. 15, 2017, doi: 10.24964/ja.v5i1.253.

[2] W. Agustiningsih, "Pengaruh Penerapan E-Filing, Tingkat Pemahaman Perpajakan Dan Kesadaran Wajib Pajak Terhadap Kepatuhan Wajib Pajak Di Kpp Pratama Yogyakarta," Nominal, 
vol. V, no. 4, pp. 107-122, 2016.

[3] N. Nyoman, T. Mahaputri, and N. Noviari, "Sosialisasi Perpajakan Memoderasi Pengaruh Kesadaran Wajib Pajak dan Kualitas Pelayanan Pada Kepatuhan Wajib Pajak Badan," Fak. Ekon. dan Bisnis, Univ. Udayana (Unud), Bali, Indones., vol. 17, no. 32, pp. 2321-2351, 2016.

[4] A. Sani and A. Habibie, "Pengaruh Moral Wajib Pajak, Sikap Wajib Pajak dan Norma Subjektif terhadap Kepatuhan Pajak melalui Pemahaman Akuntansi," J. Ilman, vol. 5, no. 2, pp. 80-96, 2018, doi: 10.31227/osf.io/3h48e.

[5] L. S. N. Yanti, I. N. P. Yasa, and P. E. D. M. Dewi, "Pengaruh Sikap Wajib Pajak, Moralitas Pajak Dan Keadilan Distributif Terhadap Tingkat Kepatuhan Wajib Pajak Orang Pribadi Dalam Membayar Pajak Pada Kantor Pelayanan Pajak Pratama Gianyar," e-Journal S1 Ak Univ. Pendidik. Ganesha, vol. 8, no. 2, 2017.

[6] M. Wahyuni, N. L. G. E. Sulindawati, and N. P. Yasa, "Pengaruh Sikap dan Niat Berperilaku Patuh terhadap Kepatuhan Wajib Pajak Orang Pribadi," e-Journal S1 Ak Univ. Pendidik. Ganesha Jur. Akunt. Progr. S1, vol. 8, no. 2, pp. 1-11, 2017.

[7] E. R. N. Ariyanti, N. F. Chikmawati, and L. Evita, "Penyuluhan Hukum Hak dan Kewajiban Wajib Pajak Bagi Peserta Didik Sekolah Menengah Atas Negeri SMA N 10 Jakarta Pusat," J. Pengabdi. Kpd. Masy., vol. 23, no. 2, p. 261, 2017, doi: 10.24114/jpkm.v23i2.6874.

[8] L. Suryani, "Pengaruh Sikap, Norma Subjektif, dan Kontrol Perilaku Persepsian Terhadap Kepatuhan Wajib Pajak Orang Pribadi di Daerah Istimewa Yogyakarta dengan Niat Mematuhi Pajak sebagai Variabel Pemoderasi," J. Chem. Inf. Model., pp. 1-192, 2017.

[9] K. Artha and P. Setiawan, "Pengaruh Kewajiban Moral, Kualitas Pelayanan, Dan Sanksi Perpajakan Pada Kepatuhan Wajib Pajak Di Kpp Badung Utara," E-Jurnal Akunt., vol. 17, no. 2, pp. 913-937, 2016.

[10] I. F. P. Pertiwi, "Moral Pajak: Sebuah Opsi Peningkatan Kepatuhan Pajak Masyarakat Muslim," IAIN Surakarta, vol. 5, no. June, pp. 12-25, 2016.

[11] G. T. Boediono, R. Sitawati, and S. Harjanto, "Analisis Pengaruh Sosialisasi Perpajakan Terhadap Kepatuhan Wajib Pajak Dengan Kesadaran Sebagai Variabel Mediasi," J. Penelitan Ekon. dan Bisnis, vol. 3, no. 1, pp. 22-37, 2019, doi: 10.33633/jpeb.v3i1.2286.

[12] L. Y. Ramadhan, "Pengaruh Kesadaran, Moralitas dan Budaya Pajak Terhadap Kepatuhan Pajak (Studi Pada UKM Siola Kota Surabaya)," Equity, pp. 16-33, 2017, [Online]. Available: http://fe.ubhara.ac.id/ojs/index.php/equity/article/download/411/387.

[13] J. Subarkah and M. W. Dewi, "Pengaruh Pemahaman, Kesadaran, Kualitas Pelayanan, Dan Ketegasan Sanksi Terhadap Kepatuhan Wajib Pajak Orang Pribadi Di Kpp Pratama Sukoharjo," J. Akunt. dan Pajak, vol. 17, no. 02, pp. 61-72, 2017, doi: 10.29040/jap.v17i02.210.

[14] M. H. Ma'ruf and S. Supatminingsih, "Faktor-Faktor yang Mempengaruhi Kepatuhan Wajib Pajak Orang Pribadi," Jur. S1 Akuntansi, Univ. Pelita Harapan Email, no. 28, pp. 146-154, 2018.

[15] M. Herryanto and A. A. Toly, "Pengaruh kesadaran wajib pajak, kegiatan sosialisasi perpajakan, dan pemeriksaan pajak terhadap penerimaan pajak penghasilan di KPP Pratama Surabaya Sawahan," Tax Account. Rev., vol. 1, no. 1, pp. 125-133, 2013.

[16] H. Saputra, "Analisa Kepatuhan Pajak Dengan Pendekatan Teori Perilaku Terencana (Theory of Planned Behavior) (Terhadap Wajib Pajak Orang Pribadi Di Provinsi Dki Jakarta)," J. Muara Ilmu Ekon. dan Bisnis, vol. 3, no. 1, p. 47, 2019, doi: 10.24912/jmieb.v3i1.2320.

[17] D. Lesmana, D. Panjaitan, and M. Maimunah, "Tax Compliance Ditinjau dari Theory of Planned Behavior (TPB): Studi Empiris Pada Wajip Pajak Orang Pribadi dan Badan yang Terdaftar Pada KPP di Kota Palembang," InFestasi, vol. 13, no. 2, p. 354, 2018, doi: 10.21107/infestasi.v13i2.3514.

[18] M. Mahmudah and D. D. Iskandar, "Analisis Dampak Tax Morale Terhadap Kepatuhan Pajak UMKM: Studi Kasus Kota Semarang," J. Din. Ekon. Pembang., vol. 1, no. 1, p. 14, 2018, doi: 10.14710/jdep.1.1.14-32.

[19] T. Y. Azisah, "Pengaruh Moral Pajak, Peran Account Representative, dan Biaya Kepatuhan Pajak Terhadap Kepatuhan Pajak ( Studi Kasus Wajib Pajak yang Terdaftar di Kantor Pelayanan Pajak 
Pratama Karanganyar)," Fak. Ekon. dan Bisnis Islam Inst. Agama Islam Negeri Surakarta, vol. 11, no. 1, pp. 1-14, 2019.

[20] S. Sriniyati, "Pengaruh Moral Pajak, Sanksi Pajak, dan Kebijakan Pengampunan Pajak Terhadap Kepatuhan Pajak Wajib Pajak Orang Pribadi," J. Akuntansi, Ekon. dan Manaj. Bisnis, vol. 8, no. 1, pp. 14-23, 2020, doi: 10.30871/jaemb.v8i1.1913.

[21] N. W. M. Djudi and R. Y. Dewantara, "Analisis Kepatuhan Wajib Pajak Terhadap Peraturan Daerah Kota Malang Nomor 16 Tahun 2010 Kategori Pajak Rumah Kos," Angew. Chemie Int. Ed. 6(11), 951-952., vol. 7, no. 1, pp. 5-24, 2015.

[22] I. N. P. Yasa and M. A. Prayudi, "Perilaku Kepatuhan Perpajakan Dalam Perspektif Teori Perilaku Terencana," Semin. Nas. Ris. Inov., vol. 3, pp. 247-252, 2017.

[23] R. Syaiful, "Pengaruh kesadaran wajib pajak, administrasi perpajakan, dan sanksi pajak terhadap kepatuhan wajib pajak pajak bumi dan bangunan," 2016. 